\title{
Pengaruh Inflasi Dan BI Rate Terhadap Harga Saham Perusahaan LQ45 Pada Bursa Efek Indonesia
}

\author{
Risa Ratna Gumilang, Dikdik Nadiansyah \\ STIE Sebelas April Sumedang \\ risa@stie11april-sumedang.ac.id
}

\begin{abstract}
ABSTRAK
Penelitian ini di latarbelakangi oleh adanya ketidaksesuaian antara teori mengenai pergerakan harga saham yang dipengaruhi oleh tingkat inflasi dan BI Rate dengan kondisi yang terjadi di lapangan. Secara teori, ketika harga saham mengalami kenaikan, maka akan dipengaruhi oleh turunnya tingkat inflasi dan BI Rate, begitupun sebaliknya. Namun hal ini berbeda dengan kondisi yang terjadi di lapangan. Penelitian ini bertujuan untuk menguji dan mengetahui pengaruh inflasi dan BI Rate terhadap harga saham perusahaan LQ45. Penelitian ini menggunakan metode kuantitatif dengan menggunakan data sekunder. Dari hasil penelitian dengan menggunakan uji t, inflasi memiliki nilai thitung 0,828 dan nilai Sig. 0,417. Hal ini menunjukkan bahwa secara parsial, inflasi tidak terdapat pengaruh yang signifikan terhadap harga saham. Sementara BI Rate memiliki nilai $-t_{\text {hitung }}-2,511$ dan nilai Sig. 0,020. Hal ini menunjukkan bahwa secara parsial, BI Rate terdapat pengaruh yang signifikan terhadap harga saham. Secara korelasi, inflasi memiliki nilai Sign. (2-tailed) 0,068. Hal ini menunjukkan bahwa secara korelasi, inflasi tidak terdapat hubungan yang signifikan terhadap BI Rate. Secara simultan (uji F), inflasi dan BI Rate memiliki nilai $F_{\text {hitung }}$ 5,005 dan nilai Sig. (2-tailed) sebesar 0,017. Hal ini menunjukkan bahwa secara simultan, Inflasi dan BI Rate terdapat pengaruh yang signifikan terhadap Harga Saham.
\end{abstract}

Kata kunci : BI Rate, Inflasi, Harga Saham.

\begin{abstract}
This research is motivated by a mismatch between theories regarding stock price movements that are influenced by inflation rates and BI Rate with conditions that occur in the field. In theory, when stock prices increase, it will be influenced by falling inflation and the BI Rate, and vice versa. But this is different from the conditions that occur in the field. This research aims to examine and determine the effect of inflation and BI Rate on the LQ45 company stock prices. This study uses the quantitative method by using the secondary data. From the results of the study using the t test, inflation has a $t_{\text {count }} 0.828$ and a Sig. 0.417. This shows that partially, inflation does not have a significant effect on stock prices. While the BI Rate has a value of -2.511 and a Sig. 0.020. This shows that partially, the BI Rate has a significant effect on stock prices. In correlation, inflation has a Sign value. (2-tailed) 0.068. This shows that in correlation, inflation does not have a significant relationship to the BI Rate. Simultaneously (F test), inflation and the BI Rate have a Fcount value of 5.005 and a Sig. (2-tailed) of 0.017. This shows that simultaneously, inflation and the BI Rate have a significant effect on stock prices.
\end{abstract}

Keywords: BI Rate, Inflation, Stock Prices.

\section{PENDAHULUAN}

Keberadaan pasar modal tentunya memiliki peranan penting dalam dunia bisnis, serta dapat memberikan kemudahan dalam menghimpun dana dari masyarakat yang ingin menginvestasikan uangnya di pasar modal atau dalam bentuk saham pada sebuah perusahaan.

Harga saham yang berlaku pada bursa saham tentunya mengalami fluktuasi setiap waktunya, tentu hal ini menjadi daya tarik tersendiri bagi para investor untuk memahami perkembangan harga saham pada bursa efek. Dengan semakin tingginya harga saham yang dibeli dan didukung dengan performa perusahaan yang baik, maka tingkat return yang akan diterima oleh investor akan tinggi pula, begitupun sebaliknya.

Secara teori, perubahan harga saham dipengaruhi oleh beberapa variabel makro ekonomi, dua diantaranya yaitu Inflasi dan BI Rate. Inflasi yang mengakibatkan harga-harga produk di pasaran menjadi naik, membuat profit perusahaan menjadi menurun serta akan melemahkan harga saham. Sementara, dengan adanya kebijakan pemerintah dalam menetapkan tingkat BI Rate membuat perusahaan bersaing dalam menarik minat investor dalam mengalokasikan dananya. 
Tabel 1. Perkembangan Inflasi, BI Rate dan Rata-rata Harga Saham Perusahaan LQ45 Pada Bursa Efek Indonesia Periode 2016-2018

\begin{tabular}{ccccccc}
\hline Tahun & $\begin{array}{c}\text { Rata- } \\
\text { rata } \\
\text { Harga } \\
\text { Saham } \\
\text { (Rp) }\end{array}$ & Ket. & Inflasi & Ket. & $\begin{array}{c}\text { BI } \\
\text { Rate }\end{array}$ & Ket. \\
\hline 2016 & $7,082.40$ & - & $3.02 \%$ & - & $4.75 \%$ & - \\
2017 & $7,934.20$ & Naik & $3.61 \%$ & Naik & $4.25 \%$ & Turun \\
2018 & $8,368.60$ & Naik & $3.13 \%$ & Turun & $6.00 \%$ & Naik \\
\hline
\end{tabular}

Sumber : www.idx.co.id dan www.bi.go.id.

Berdasarkan data di atas, pada tahun 2017 dan 2018. terdapat ketidaksesuaian antara teori dengan kondisi di lapangan. Dimana pada tahun 2017, diduga inflasi tidak berpengaruh terhadap harga saham karena inflasi dan harga saham mengalami kenaikan secara bersamaan. Sementara BI Rate diduga berpengaruh terhadap harga saham, karena BI Rate dan harga saham memilki arah yang berlawanan.

Untuk tahun 2018, diduga inflasi memiliki pengaruh terhadap harga saham, karena memiliki arah yang berlawanan. Sementara BI Rate diduga tidak memiliki pengaruh terhadap harga saham, karena BI Rate dan harga saham mengalami kenaikan secara bersamaan.

\section{Rumusan Masalah}

Mengacu dari latar belakang di atas, maka rumusan masalah dalam penelitian ini sebagai berikut:

1. Bagaimana pengaruh Inflasi terhadap Harga Saham pada Perusahaan LQ45 yang tercatat pada Bursa Efek Indonesia periode 2017-2018?

2. Bagaimana pengaruh BI Rate terhadap Harga Saham pada Perusahaan LQ45 yang tercatat pada Bursa Efek Indonesia periode 2017-2018?

3. Bagaimana hubungan antara Inflasi dan BI Rate periode 2017-2018?

4. Bagaimana pengaruh Inflasi dan BI Rate terhadap Harga Saham pada Perusahaan LQ45 yang tercatat pada Bursa Efek Indonesia periode 2017$2018 ?$

\section{Tujuan Penelitian}

Berdasarkan rumusan masalah di atas, maka tujuan penelitian ini adalah :

1. Untuk mengetahui pengaruh Inflasi terhadap Harga Saham pada Perusahaan LQ45 yang tercatat pada Bursa Efek Indonesia periode 2017-2018.

2. Untuk mengetahui pengaruh BI Rate terhadap Harga Saham pada Perusahaan LQ45 yang tercatat pada Bursa Efek Indonesia periode 2017-2018.

3. Untuk mengetahui hubungan antara Inflasi dan BI Rate periode 2017-2018.

4. Untuk mengetahui pengaruh Inflasi dan BI Rate terhadap Harga Saham Perusahaan LQ45 yang tercatat pada Bursa Efek Indonesia periode 2017 2018.

\section{KAJIAN PUSTAKA}

\section{Pasar Modal}

Irham Fahmi (2015:48) menyatakan bahwa pasar modal (capital market) adalah tempat bagi berbagai pihak (khususnya perusahaan) untuk menjual saham (stock) dan obligasi (bond). Hasil dari penjualan tersebut nantinya akan digunakan sebagai tambahan dana atau untuk memperkuat modal perusahaan.

\section{Saham}

Irham Fahmi (2015:80) menyatakan bahwa saham (stock) adalah tanda bukti penyertaan kepemilikan modal/dana pada suatu perusahaan dan atau kertas yang tercantum dengan jelas nilai nominal, nama perusahaan dan diikuti dengan hak dan kewajiban yang dijelaskan kepada setiap pemegangnya.

\section{Harga Saham}

Menurut Anoraga dalam Haslita Nisa (2018:33) menyatakan bahwa Harga saham adalah nilai sekarang dari arus kas yang akan diterima oleh pemilik saham di kemudian hari. Harga saham dapat menunjukkan nilai suatu perusahaan, dimana ketika perusahaan menjual sahamnya dengan harga tinggi maka nilai perusahaan tersebut baik, begitupun sebaliknya. Pengukuran dari harga saham ini yaitu harga penutupan saham (closing price) tiap perusahaan yang diperoleh dari harga saham pada periode akhir tahun.

\section{Inflasi}

Ebert dan Griffin dalam Werner R. Murhadi (2015:72) menjelaskan bahwa inflasi merupakan kondisi dimana jumlah barang yang beredar lebih sedikit dari jumlah permintaan sehingga akan mengakibatkan terjadinya kenaikan harga yang meluas dalam sistem perekonomian secara keseluruhan. Pengukuran tingkat inflasi yang digunakan yaitu berdasarkan pengukuran Indeks Harga Konsumen (IHK) atau Consumer Price Index (CPI).

Consumer Price Index adalah indeks yang paling banyak digunakan dalam penghitungan inflasi. Indeks ini disusun dari harga barang dan jasa yang dikonsumsi oleh masyarakat. Jumlah barang dan jasa yang digunakan dalam penghitungan angka indeks tersebut berbeda antar negara dan antar waktu, bergantung pada pola konsumsi masyarakat akan barang dan jasa tersebut.

$$
\mathrm{IR}_{\mathbf{x}}=\frac{\mathrm{CPI}-\left.\mathrm{CP}\right|_{\mathrm{x}-1}}{\mathrm{CPI}_{\mathrm{x}-1}} \times 100
$$




\section{BI Rate}

Menurut Kasmir (2016:114) berpendapat bahwa bunga bank dapat diartikan sebagai balas jasa yang diberikan oleh bank yang berdasarkan prinsip konvensional kepada nasabah yang membeli atau menjual produknya.

Suku bunga SBI dihitung menggunakan metode rata-rata tertimbang dengan membobot suku bunga dengan volume transaksi SBI di masing-masing suku bunga yang tidak melebihi $S O R$ pada setiap periode lelang. Stop Out Rate (SOR) adalah tingkat diskonto tertinggi yang dihasilkan dari lelang dalam rangka mencapai target kuantitas SBI yang akan diterbitkan oleh Bank Indonesia.

\section{Suku Bunga $=\frac{(\text { vol } 1 \times \text { rate1 })+(\text { vol } 2 x \text { rate } 2)+(\text { vol } 3 \times \text { rate3 })+(\text { volN x rateN })}{\text { Total Volume }} \rightarrow$}

\section{Kerangka Pemikiran}

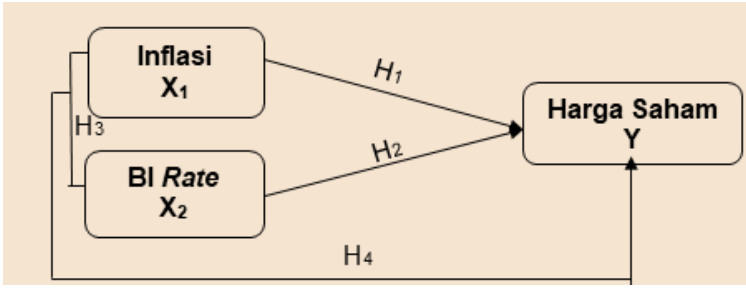

Gambar 1. Kerangka Pemikiran

\section{Hipotesis Penelitian}

$\mathrm{H}_{1}$ : Diduga terdapat pengaruh yang signifikan antara Inflasi terhadap harga saham.

$\mathrm{H}_{2}$ : Diduga terdapat pengaruh yang signifikan antara BI Rate terhadap harga saham.

$\mathrm{H}_{3}$ : Diduga terdapat hubungan antara Inflasi dan BI Rate.

$\mathrm{H}_{4}$ : Diduga terdapat pengaruh yang signifikan antara Inflasi dan BI Rate terhadap harga saham.

\section{METODOLOGI PENELITIAN}

Metode yang digunakan dalam penelitian ini adalah metode kuantitatif. Sugiyono (2018:35-36) menyatakan bahwa metode kuantitatif dapat diartikan sebagai metode penelitian yang berlandaskan pada filsafat positivisme, digunakan untuk meneliti pada populasi atau sampel tertentu, pengumpulan data menggunakan instrumen penelitian, analisis data bersifat kuantitatif/statistik, dengan tujuan untuk menguji hipotesis yang telah ditetapkan. Variabel dalam penelitian ini terdiri dari dua variabel independen dan satu variabel dependen. Variabel independen dalam penelitian ini adalah Inflasi dan BI Rate, sementara variabel dependennya adalah Harga Saham. Sumber data yang digunakan dalam penelitian ini adalah data sekunder dari situs resmi Bursa Efek Indonesia dan Bank Indonesia. Sementara untuk teknik pengumpulan datanya, penulis mengumpulkan data menggunakan dokumentasi, studi kepustakaan dan studi internet.

Populasi dalam penelitian ini adalah perusahaan LQ45 yang terdaftar di Bursa Efek Indonesia periode 2017-2018 yang berjumlah 45 perusahaan. Teknik pengambilan sampel yaitu metode purposive sampling. Sugiyono (2018:156) menyatakan bahwa purposive sampling adalah teknik penentuan sampel dengan pertimbangan tertentu. Sampel yang diambil dalam penelitian ini sebanyak 28 perusahaan, diluar perusahaan delisting selama tahun 2017 dan 2018 yaitu 12 perusahaan dan 5 perusahaan perbankan.

Setelah memperoleh data-data yang dibutuhkan dalam penelitian ini, maka penulis membuat rancangan analisis data untuk menginterprestasikan hasil perhitungan dan menjawab masalah yang diteliti serta menarik kesimpulan dari pengolahan data tersebut. Analisis data yang digunakan dalam penelitian ini yaitu menggunakan analisis regresi linier berganda, dimana perlu dilakukan uji asumsi klasik terlebih dahulu sebagai syarat dalam penggunaan analisis data ini sehingga memberikan hasil yang Blue Linear Unbiased Estimator (BLUE) jika uji asumsi klasik terpenuhi. Selain itu, sebelum dilakukan uji asumsi klasik, penulis juga melakukan analisis statistik deskriptif. Sementara alat yang digunakan untuk pengolahan data dalam penelitian ini yaitu menggunakan software SPSS (Statistical Package for Social Sciences) versi 25.

\section{Analisis Statistik Deskriptif}

Imam Ghozali (2018:19) menyatakan bahwa statistik deskriptif memberikan gambaran atau deskripsi suatu data yang dilihat dari nilai rata-rata (mean), standar deviasi, varian, maksimum, minimum, sum, range, kurtosis, dan skewness (kemencengan distribusi).

\section{Uji Asumsi Klasik}

Uji asumsi klasik adalah persyaratan statistik yang harus dipenuhi pada analisis regresi linear berganda yang berbasis ordinary least square (OLS). Dalam tahap uji asumsi klasik, berikut ini adalah 5 model pengujian yang digunakan yaitu:

\section{Uji Normalitas}

Imam Ghozali (2018:161) menyatakan bahwa uji normalitas bertujuan untuk menguji apakah dalam model regresi, variabel pengganggu atau residual memiliki distribusi normal.

\section{Uji Multikolinearitas}

Imam Ghozali (2018:107) menyatakan bahwa uji multikolonieritas bertujuan untuk menguji apakah 
model regresi ditemukan adanya korelasi antar variabel bebas (independen).

\section{Uji Heteroskedastisitas}

Imam Ghozali (2018:137) menyatakan bahwa uji heteroskedastisitas bertujuan untuk menguji apakah dalam model regresi terjadi ketidaksamaan variance dari residual satu pengamatan ke pengamatan yang lain.

\section{Uji Autokorelasi}

Imam Ghozali (2018:111) menyatakan bahwa uji autokorelasi bertujuan untuk menguji apakah dalam model regresi linear ada korelasi antara kesalahan pengganggu pada periode $\mathrm{t}$ dengan kesalahan pengganggu pada periode $\mathrm{t}-1$ (sebelumnya).

\section{Uji Linearitas}

Imam Ghozali (2018:167) menyatakan bahwa uji linearitas digunakan untuk melihat apakah spesifikasi model yang digunakan sudah benar atau tidak. Selain itu, uji linearitas bertujuan untuk mengetahui apakah dua variabel mempunyai hubungan yang linear secara signifikan atau tidak.

\section{Regresi Linear Berganda}

Dalam penelitian ini, analisis linear berganda digunakan untuk membuktikan bagaimana pengaruh Inflasi dan BI Rate terhadap Harga Saham perusahaan LQ45 pada Bursa Efek Indonesia (BEI). Persamaan umum regresi linear berganda, yaitu:

$$
Y=\beta_{0}+\beta_{1} X_{1}+\beta_{2} X_{2}+\varepsilon
$$

$$
\begin{array}{ll}
\text { Dimana: } \\
\mathbf{Y} & =\text { Harga Saham } \\
\boldsymbol{\beta}_{\mathbf{0}} & =\text { Konstanta } \\
\boldsymbol{\beta}_{\mathbf{1}} & =\text { Koefisien Regresi } \\
\mathbf{X}_{\mathbf{1}} & =\text { Inflasi } \\
\mathbf{X}_{\mathbf{2}} & =\text { BI Rate } \\
\boldsymbol{\varepsilon} & =\text { Kesalahan }
\end{array}
$$

\section{Pengujian Hipotesis}

\section{Analisis Koefisien Korelasi dan Koefisien Determinasi}

Eduardus Tandelilin (2017:127) menyatakan bahwa koefisien korelasi adalah suatu ukuran statistik yang menunjukkan pergerakan bersamaan relatif (relative comovements) antara dua variabel. Dalam penelitian ini, pengujian ini dilakukan untuk mengetahui hubungan antara Inflasi dan BI Rate. Sementara untuk mengukur besarnya pengaruh variabel independen terhadap variabel dependen, digunakan koefisien determinasi.

\section{Pengujian Hipotesis secara Parsial (Uji T)}

Uji $\mathrm{t}$ adalah pengujian terhadap koefisien regresi secara parsial. Uji $t$ ini bertujuan untuk menguji bagaimana pengaruh masing-masing variabel independennya secara sendiri-sendiri terhadap variabel dependen. Dalam penelitian ini, tingkat kesalahan yang digunakan adalah sebesar 5\% dengan degree of freedom atau derajat bebas pada $\mathrm{t}_{\text {tabel }} \mathrm{Df}=\mathrm{n}-\mathrm{k}$.

\section{Pengujian Hipotesis secara Simultan (Uji F)}

Uji $\mathrm{F}$ adalah pengujian terhadap koefisien regresi secara simultan. Uji F ini bertujuan untuk menguji bagaimana pengaruh semua variabel independennya secara bersama-sama (simultan) terhadap variabel dependen. Dalam penelitian ini, tingkat kesalahan yang digunakan adalah sebesar 5\% dengan degree of freedom atau derajat bebas pada $\mathrm{F}_{\text {tabel }} \mathrm{Df}_{1}=\mathrm{k}-1$ dan $\mathrm{Df}_{2}=\mathrm{n}-\mathrm{k}$.

\section{HASIL PENELITIAN}

Penelitian ini bertujuan untuk menguji dan mengetahui pengaruh Inflasi dan BI Rate sebagai variabel independen (variabel bebas) terhadap Harga Saham sebagai variabel dependen (variabel terikat) pada perusahaan LQ45 pada Bursa Efek Indonesia periode 2017-2018.

\section{Analisis Statistik Deskriptif}

Imam Ghozali (2018:19) menyatakan bahwa statistik deskriptif memberikan gambaran atau deskripsi suatu data yang dilihat dari nilai rata-rata (mean), standar deviasi, varian, maksimum, minimum, sum, range, kurtosis, dan skewness (kemencengan distribusi).

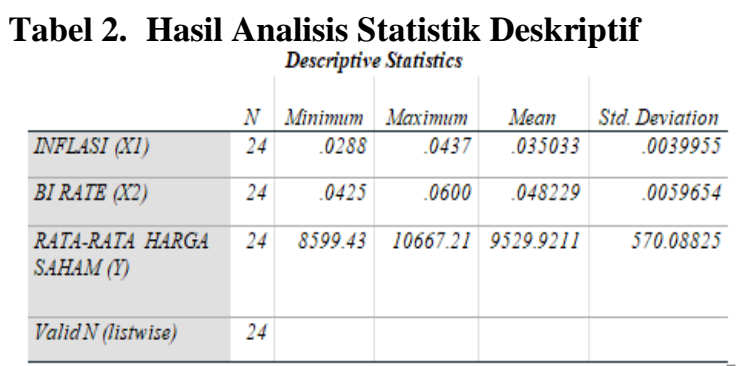

\section{Sumber: Hasil output SPSS versi 25.}

\section{Uji Asumsi Klasik}

\section{Uji Normalitas}

Dalam pengujian ini, penulis melakukan dua cara uji normalitas data, yaitu melalui analisis grafik dengan normal probability plot. Serta melakukan analisis statistik One Sample Kolmogorov Smirnov. 


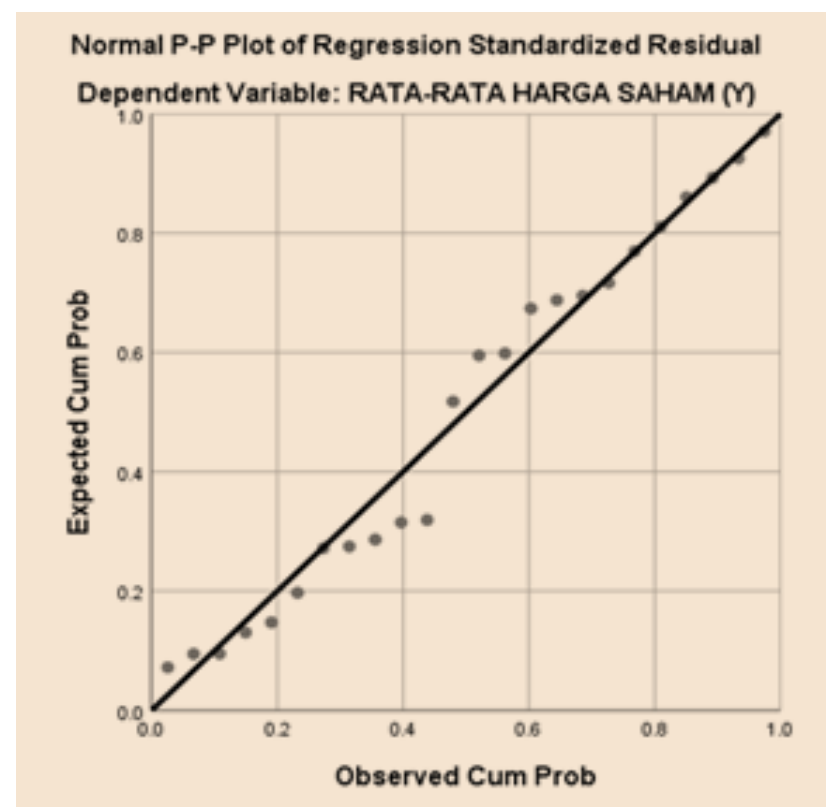

Gambar 2. Hasil Uji Normalitas Normal Probability Plot

Berdasarkan hasil pengujian diatas, dapat terlihat dengan jelas bahwa titik-titik (data) menyebar di sekitar garis diagonal dan mengikuti arah garis diagonal menunjukkan pola distribusi normal, maka model regresi memenuhi asumsi normalitas.

Untuk memperkuat dan membuktikan hasil analisis normal probability plot di atas, maka penulis juga melakukan analisis statistik One Sample Kolmogorov Smirnov. Dimana residual dikatakan berdistribusi normal jika nilai signifikansi lebih besar dari 0,05 dan residual dikatakan tidak berdistribusi normal jika nilai signifikansi kurang dari 0,05 .

Tabel 3. Hasil One-Sample Kolmogorov-Smirnov Test

\begin{tabular}{|c|c|c|}
\hline & & $\begin{array}{c}\text { Unstandardize } \\
\text { d Residual }\end{array}$ \\
\hline$N$ & & 24 \\
\hline \multirow{2}{*}{ Normal Parameters ${ }^{a, b}$} & Mean & .0000000 \\
\hline & Std. Deviation & 469.14233551 \\
\hline \multirow[t]{3}{*}{ Most Extreme Differences } & Absolute & .147 \\
\hline & Positive & .147 \\
\hline & Negative & -.099 \\
\hline \multicolumn{2}{|l|}{ Test Statistic } & .147 \\
\hline \multicolumn{2}{|l|}{ Asymp. Sig. (2-tailed) } & $.195^{c}$ \\
\hline \multicolumn{3}{|c|}{ a. Test distribution is Normal. } \\
\hline \multicolumn{3}{|l|}{ b. Calculated from data. } \\
\hline \multicolumn{3}{|c|}{ c. Lilliefors Significance Correction. } \\
\hline
\end{tabular}

Sumber: Hasil output SPSS versi 25.

Berdasarkan uji One-Sample Kolmogorov-Smirnov, dapat diketahui bahwa nilai signifikansi atau Asymp. Sig. (2-tailed) yaitu sebesar 0,195. Nilai tersebut lebih besar dari 0,05 yang berarti data dalam model regresi ini berdistribusi normal. 


\section{Uji Multikolinearitas}

Berdasarkan uji multikolonieritas, diperoleh hasil sebagai berikut:

\section{Tabel 4. Hasil Uji Multikolonieritas}

\begin{tabular}{|c|c|c|c|}
\hline \multicolumn{4}{|c|}{ Coefficients $^{a}$} \\
\hline \multirow{2}{*}{\multicolumn{2}{|c|}{ Model }} & Collit & itatistics \\
\hline & & Tolerance & $V I F$ \\
\hline \multirow[t]{2}{*}{$\bar{l}$} & INFLASI $(X I)$ & .856 & 1.168 \\
\hline & BI RATE $(X 2)$ & .856 & 1.168 \\
\hline
\end{tabular}

\section{Sumber: Hasil output SPSS versi 25.}

Berdasarkan hasil uji multikolonieritas, dapat dilihat bahwa nilai Tolerance Inflasi dan BI Rate sebesar 0,856 atau lebih besar dari 0,100 dan nilai VIF inflasi dan BI Rate sebesar 1,168 atau lebih kecil dari 10. Nilai tersebut menunjukkan bahwa kedua variabel dalam model regresi ini tidak terjadi multikolonieritas.

\section{Uji Heteroskedastisitas}

Berdasarkan uji heteroskedastisitas, diperoleh hasil sebagai berikut:

\section{Tabel 5. Hasil Uji Heteroskedastisitas}

\begin{tabular}{|c|c|c|c|c|c|}
\hline \multirow[b]{3}{*}{ Model } & \multicolumn{2}{|r|}{ Coefficients $^{a}$} & \multirow[b]{2}{*}{$\begin{array}{l}\text { Standardized } \\
\text { Coefficients }\end{array}$} & \multirow[b]{3}{*}{$t$} & \multirow[b]{3}{*}{ Sig. } \\
\hline & \multicolumn{2}{|c|}{ Unstandardized Coefficients } & & & \\
\hline & $B$ & Std. Error & Beta & & \\
\hline I (Constant) & 20.719 & 4.810 & & 4.308 & .000 \\
\hline INFLASI $(X I)$ & -113.091 & 85.808 & -285 & -1.318 & .202 \\
\hline BIRATE $(X 2)$ & -107.688 & 57.472 & -.405 & -1.874 & .075 \\
\hline
\end{tabular}

a. Dependent Variable: LNU2i

Sumber: Hasil output SPSS versi 25

Berdasarkan hasil uji heteroskedastisitas dengan menggunakan uji park dapat diketahui bahwa nilai signifikansi (Sig.) inflasi dan BI Rate yaitu masing- masing sebesar 0,202 dan 0,075 atau lebih besar dari 0,05. Nilai tersebut menunjukkan bahwa dalam model regresi ini tidak terjadi gejala heteroskedastisitas.

\section{Uji Autokorelasi}

Berdasarkan uji autokorelasi, diperoleh hasil sebagai berikut:

\section{Tabel 6. Hasil Uji Autokorelasi}

\begin{tabular}{lr} 
& Runs Test \\
& Unstandardized Residual \\
\hline Test Value & \\
\hline Cases $<$ Test Value & 69.87054 \\
\hline Cases $>=$ Test Value & 12 \\
\hline Total Cases & 12 \\
\hline Number of Runs & 24 \\
\hline Z & 8 \\
\hline Asymp. Sig. (2-tailed) & -1.878 \\
\hline a. Median & .060 \\
\hline
\end{tabular}

Sumber: Hasil output SPSS versi 25.

Berdasarkan hasil uji autokorelasi dengan menggunakan metode uji run test, dapat diketahui bahwa nilai Asymp. Sig. (2-tailed) sebesar 0,060 atau lebih besar dari 0,05. Nilai ini menunjukkan bahwa model regresi terbebas dari gejala autokorelasi.

\section{Uji Linearitas}

Berdasarkan uji linearitas, diperoleh hasil sebagai berikut:

Tabel 7. Hasil Uji Linearitas Inflasi dengan Rata-rata Harga Saham

ANOVA Table

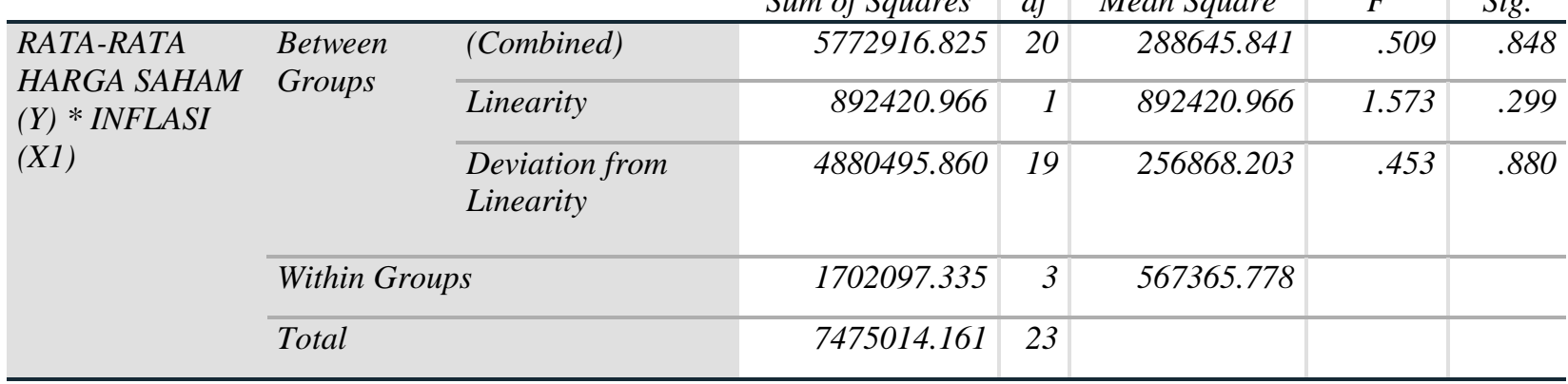

\section{Sumber: Hasil output SPSS versi 25.}

Berdasarkan hasil uji linearitas diatas, dapat diketahui bahwa nilai deviation from linearity Sig. sebesar 0,880 atau lebih besar dari 0,05. Nilai ini menunjukkan bahwa variabel inflasi dengan ratarata harga saham terdapat hubungan yang linear secara signifikan 
Tabel 8. Hasil Uji Linearitas BI Rate dengan Rata-rata Harga Saham

\begin{tabular}{|c|c|c|c|c|c|c|c|}
\hline & & & OVA Table & & & & \\
\hline & & & Sum of Squares & $D f$ & Mean Square & $F$ & Sig. \\
\hline$R A T A-R A T A$ & Between & (Combined) & 3294334.424 & 6 & 549055.737 & 2.233 & .090 \\
\hline$(Y) * B I R A T E(X 2)$ & & Linearity & 2247444.968 & 1 & 2247444.968 & 9.139 & .008 \\
\hline & & $\begin{array}{l}\text { Deviation from } \\
\text { Linearity }\end{array}$ & 1046889.456 & 5 & 209377.891 & .851 & .533 \\
\hline & Within $G$ & & 4180679.736 & 17 & 245922.337 & & \\
\hline & Total & & 7475014.161 & 23 & & & \\
\hline
\end{tabular}

Sumber: Hasil output SPSS versi 25.

Berdasarkan hasil uji linearitas pada tabel 4.11, dapat diketahui bahwa nilai deviation from linearity Sig. sebesar 0,533 atau lebih besar dari 0,05. Nilai ini menunjukkan bahwa variabel BI Rate dengan rata-rata harga saham terdapat hubungan yang linear secara signifikan.

\section{Regresi Linear Berganda}

Berdasarkan uji regresi linear berganda, diperoleh hasil sebagai berikut:

Tabel 9. Hasil Uji Regresi Linear Berganda

\begin{tabular}{|c|c|c|c|c|c|c|}
\hline \multicolumn{7}{|c|}{ Coefficients ${ }^{a}$} \\
\hline \multirow{2}{*}{\multicolumn{2}{|c|}{ Model }} & \multicolumn{2}{|c|}{ Unstandardized Coefficients } & \multirow{2}{*}{$\begin{array}{c}\text { Standardized } \\
\text { Coefficients } \\
\text { Beta } \\
\end{array}$} & \multirow[b]{2}{*}{$T$} & \multirow[b]{2}{*}{ Sig. } \\
\hline & & B & Std. Error & & & \\
\hline \multirow[t]{3}{*}{1} & (Constant) & 10972.752 & 1552.097 & & 7.070 & .000 \\
\hline & INFLASI (XI) & 22936.129 & 27689.675 & .161 & .828 & .417 \\
\hline & BI RATE (X2) & -46576.794 & 18545.854 & -.487 & -2.511 & .020 \\
\hline
\end{tabular}

a. Dependent Variable: RATA-RATA HARGA SAHAM (Y)

Sumber: Hasil output SPSS versi 25.

Berdasarkan hasil uji regresi linear berganda, maka dapat diketahui bentuk persamaan sebagai berikut:

Rata-rata Harga Saham =

10.976,752 + 22.936,129 Inflasi - 46.576,794 BI Rate $+\varepsilon$

Persamaan regresi di atas dapat dijelaskan sebagai berikut:

1. Nilai konstanta sebesar $10.976,752$, artinya jika nilai Inflasi $\left(\mathrm{X}_{1}\right)$ dan nilai Bi Rate $\left(\mathrm{X}_{2}\right)$ adalah 0, maka memperkirakan nilai Rata-rata Harga Sahamnya sebesar Rp 10.976,752.

2. Nilai koefisien regresi variabel Inflasi sebesar 22.936,129, artinya jika Inflasi mengalami kenaikan $1 \%$ maka nilai Rata-rata Harga Sahamnya diperkirakan sebesar Rp 22.936,129 dengan asumsi variabel independen lainnya tetap.
3. Nilai koefisien regresi variabel BI Rate sebesar $-46.576,794$, artinya jika BI Rate mengalami kenaikan $1 \%$ maka nilai Rata-rata Harga Saham diperkirakan akan turun sebesar $\mathrm{Rp}$ 46.576,794 dengan asumsi variabel independen lainnya tetap.

\section{Pengujian Hipotesis}

\section{Uji t (Pengujian secara parsial)}

Dalam penelitian ini, uji t digunakan untuk menguji ada atau tidaknya pengaruh Inflasi terhadap Harga Saham dan pengaruh BI Rate terhadap Harga Saham.

Berikut ini merupakan hasil dari pengujiannya: 
Tabel 10. Hasil Uji t

\begin{tabular}{|c|c|c|c|c|c|c|}
\hline \multicolumn{7}{|c|}{ oefficients ${ }^{a}$} \\
\hline \multirow{2}{*}{\multicolumn{2}{|c|}{ Model }} & \multicolumn{2}{|c|}{ Unstandardized Coefficients } & \multirow{2}{*}{$\begin{array}{c}\text { Standardized } \\
\text { Coefficients } \\
\text { Beta }\end{array}$} & \multirow[b]{2}{*}{$t$} & \multirow[b]{2}{*}{ Sig. } \\
\hline & & $B$ & Std. Error & & & \\
\hline \multirow[t]{3}{*}{1} & (Constant) & 10972.752 & 1552.097 & & 7.070 & .000 \\
\hline & INFLASI (X1) & 22936.129 & 27689.675 & .161 & .828 & .417 \\
\hline & BI RATE (X2) & -46576.794 & 18545.854 & -.487 & -2.511 & .020 \\
\hline
\end{tabular}

a. Dependent Variable: RATA-RATA HARGA SAHAM (Y)

Sumber: Hasil output SPSS versi 25.

Berdasarkan hasil pengujian di atas, dapat diketahui bahwa Inflasi memiliki nilai $t_{\text {hitung }}$ sebesar 0,828 dengan nilai $t_{\text {tabel }}$ pada pengujian ini sebesar 2,07961 serta nilai Sig. sebesar 0,417. Maka dapat dinyatakan bahwa $\mathrm{H}_{0}$ diterima karena nilai $\mathrm{t}_{\text {hitung }}$ $(0,828) \leq t_{\text {tabel }}(2,07961)$ dan nilai Sig. 0,417 >0,05. Sehingga dapat disimpulkan bahwa secara parsial, Inflasi tidak terdapat pengaruh yang signifikan terhadap Harga Saham.

Sementara itu, BI Rate memiliki nilai $t_{\text {hitung }}$ sebesar -2,511 dengan nilai $t_{\text {tabel }}$ pada pengujian ini sebesar $-2,07961$ serta nilai Sig. sebesar 0,020. Maka dapat dinyatakan bahwa $\mathrm{H}_{0}$ ditolak karena nilai $-\mathrm{t}_{\text {hitung }}$ $(-2,511) \leq-t_{\text {tabel }}(-2,07961)$ dan nilai Sig. $0,020<$ 0,05 . Sehingga dapat disimpulkan bahwa secara parsial, BI Rate terdapat pengaruh yang signifikan terhadap Harga Saham. Nilai $t_{\text {hitung }}$ bernilai negatif yang berarti bahwa BI Rate dan Harga Saham memiliki pengaruh yang negatif atau berlawanan, dimana ketika BI Rate mengalami kenaikan maka Harga Saham akan mengalami penurunan, begitu juga sebaliknya.

\section{Analisis Koefisien Korelasi}

Koefisien korelasi bertujuan untuk mengetahui hubungan antara variabel independen $\left(\mathrm{X}_{1}\right)$ yaitu Inflasi dengan variabel independen $\left(\mathrm{X}_{2}\right)$ yaitu $\mathrm{BI}$ Rate.

Berdasarkan pengujian yang telah dilakukan, diperoleh hasil sebagai berikut :

\section{Tabel 11. Hasil Uji Koefisien Korelasi}

\begin{tabular}{|c|c|c|c|c|}
\hline \multicolumn{5}{|c|}{ tions } \\
\hline & & INFLASI (X1) & BI RATE (X2) & $\begin{array}{c}\text { HARGA SAHAM } \\
(\mathrm{Y})\end{array}$ \\
\hline \multirow[t]{3}{*}{ INFLASI (X1) } & Pearson Correlation & 1 & -.379 & .346 \\
\hline & Sig. (2-tailed) & & .068 & .098 \\
\hline & $\mathrm{N}$ & 24 & 24 & 24 \\
\hline \multirow[t]{3}{*}{ BI RATE (X2) } & Pearson Correlation & -.379 & 1 & $-.548^{* * *}$ \\
\hline & Sig. (2-tailed) & .068 & & .006 \\
\hline & $\mathrm{N}$ & 24 & 24 & 24 \\
\hline \multirow{3}{*}{$\begin{array}{l}\text { RATA-RATA HARGA } \\
\text { SAHAM (Y) }\end{array}$} & Pearson Correlation & .346 & $-.548^{* *}$ & 1 \\
\hline & Sig. (2-tailed) & .098 & .006 & \\
\hline & $\mathrm{N}$ & 24 & 24 & 24 \\
\hline
\end{tabular}

**. Correlation is significant at the 0.01 level (2-tailed).

Sumber: Hasil output SPSS versi 25.

Berdasarkan tabel diatas, dapat diketahui bahwa hubungan inflasi dan BI Rate memperoleh nilai Sig. (2-tailed) sebesar 0,068. Maka dapat dinyatakan bahwa $\mathrm{H}_{0}$ diterima dan $\mathrm{H}_{3}$ ditolak karena nilai Sign. (2-tailed) yaitu $0,068>0,05$. Sehingga dapat disimpulkan bahwa secara korelasi, inflasi tidak terdapat hubungan yang signifikan terhadap BI Rate.
Sementara itu, besarnya pengaruh yang diberikan BI Rate terhadap harga saham ketika tingkat inflasi tetap adalah $(-0.548)^{2} \times 100 \%=30,03 \%$.

\section{Uji F (Pengujian secara simultan)}

Dalam penelitian ini, pengujian dilakukan untuk menguji bagaimana pengaruh Inflasi dan BI Rate secara simultan terhadap Harga saham.

Berdasarkan pengujian yang telah dilakukan, diperoleh hasil sebagai berikut : 
Tabel 12. Hasil Uji F

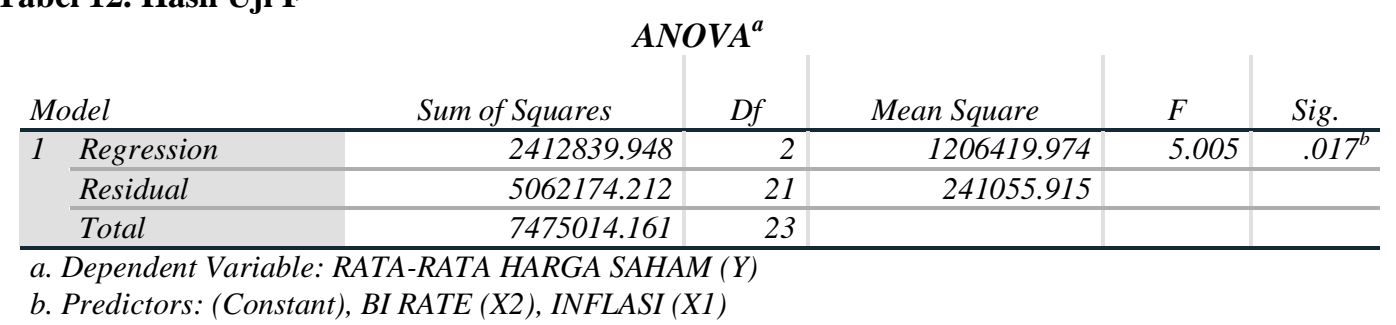

\section{Sumber: Hasil output SPSS versi 25.}

Berdasarkan hasil uji F, dapat diketahui bahwa nilai $\mathrm{F}_{\text {hitung }}$ sebesar 5,005 dan nilai Sig. (2-tailed) sebesar 0,017. Untuk nilai $F_{\text {tabel }}$ dalam penelitian ini berdasarkan $\alpha=5 \%$ dan degree of freedom atau derajat kebebasan adalah DF1 $=\mathrm{k}-1=3-1=2$, $\mathrm{DF}=\mathrm{n}-\mathrm{k}=24-3=21$ sehingga menghasilkan $\mathrm{F}_{\text {tabel }}$ sebesar 3,47. Dikarenakan nilai $\mathrm{F}_{\text {hitung }} 5,005 \geq$ $\mathrm{F}_{\text {tabel }}$ 3,47 dan nilai Sig. (2-tailed) sebesar 0,017 < 0,05. maka dapat dinyatakan bahwa $\mathrm{H}_{0}$ ditolak. Sehingga dapat disimpulkan bahwa secara simultan,
Inflasi dan BI Rate terdapat pengaruh yang signifikan terhadap Harga Saham.

\section{Koefisien Determinasi}

Dalam penelitian ini, koefisien determinasi bertujuan untuk mengukur besarnya pengaruh variabel independen yaitu Inflasi dan BI Rate terhadap variabel dependen yaitu Harga Saham.

Berdasarkan pengujian yang telah dilakukan, diperoleh hasil sebagai berikut :

Tabel 13. Hasil Uji Koefisien Determinasi

\begin{tabular}{|c|c|c|c|c|}
\hline \multicolumn{5}{|c|}{ Model Summary ${ }^{b}$} \\
\hline Model & $R$ & $R$ Square & $\begin{array}{l}\text { Adjusted } R \\
\text { Square }\end{array}$ & $\begin{array}{c}\text { Std. Error of the } \\
\text { Estimate }\end{array}$ \\
\hline 1 & $.568^{a}$ & .323 & .258 & 490.97445 \\
\hline
\end{tabular}

a. Predictors: (Constant), BI RATE (X2), INFLASI (X1)

b. Dependent Variable: RATA-RATA HARGA SAHAM $(Y)$

\section{Sumber: Hasil output SPSS versi 25.}

Berdasarkan tabel diatas, dapat diketahui bahwa nilai koefisien determinasi ( $\mathrm{R}$ Square) sebesar 0,323 atau $32,3 \%$. Hal ini menunjukkan bahwa besarnya pengaruh variabel Inflasi dan BI Rate terhadap Harga Saham sebesar 32,3\%, adapun sisanya sebesar $67,7 \%$ dipengaruhi oleh variabel lain yang tidak diteliti seperti Gross Domestic Product (GDP)/Product Domestic Bruto (PDB), nilai tukar, harga minyak, harga komoditas, Hedging, siklus bisnis dan lainnya.

\section{SIMPULAN DAN SARAN}

\section{Simpulan}

Berdasarkan hasil penelitian dan pembahasan pada penelitian ini, maka dapat disimpulkan sebagai berikut:

1. Secara parsial, inflasi tidak terdapat pengaruh yang signifikan terhadap harga saham perusahaan LQ45 pada Bursa Efek Indonesia tahun 2017-2018.

2. Secara parsial, BI Rate terdapat pengaruh yang signifikan terhadap harga saham perusahaan LQ45 pada Bursa Efek Indonesia tahun 2017-2018.
3. Inflasi tidak terdapat hubungan dengan BI Rate tahun 2017-2018.

4. Secara simultan, Inflasi dan BI Rate memiliki pengaruh yang signifikan terhadap harga saham perusahaan LQ45 pada Bursa Efek Indonesia tahun 2017-2018.

\section{Saran}

Dari hasil penelitian yang telah dilakukan, adapun saran-saran dari penulis sebagai berikut:

1. Perusahaan harus menjaga atau meningkatkan pelayanan dan kualitas produk-produknya. Sehingga perusahaan akan tetap memiliki modal dari keuntungan yang diperoleh dari penjualan produknya dan tingkat kepercayaan dari masyarakat akan tetap terjaga, sekalipun terjadi kenaikan tingkat inflasi di pasar.

2. Perusahaan harus memperhatikan pergerakan tingkat BI Rate agar dapat menetapkan harga saham yang tepat. Hal ini sebagai langkah untuk meminimalisir kehilangan investor sebagai sumber modal perusahaan. 
3. Pemerintah harus menetapkan tingkat BI Rate yang tepat agar tingkat inflasi dapat terkontrol dan mekanisme pasar bisa stabil, serta kegiatan dalam investasi di pasar modal bisa berjalan dengan baik.

4. Perusahaan harus memperhatikan kondisi pasar akibat inflasi, pergerakan tingkat BI Rate, meningkatkan kualitas produk serta pelayanan yang prima terhadap masyarakat maupun investor. Sehingga masyarakat maupun investor akan menaruh kepercayaan serta loyalitas yang baik bagi perusahaan sekalipun terdapat peningkatan BI Rate

\section{DAFTAR PUSTAKA}

Fahmi, Irham. 2015. Manajemen Investasi: Teori dan Soal Jawab. Jakarta: Salemba Empat.

Ghozali, Imam. 2018. Aplikasi Analisis Multivariate: Dengan Program IBM SPSS 25 Edisi 9. Semarang: Badan Penerbit-Undip.

Kasmir. 2016. Bank dan Lembaga Keuangan Lainnya. Jakarta:Rajawali Pers.

Murhadi, R. Werner. 2015. Analisis Laporan Keuangan, Proyeksi dan Valuasi Saham. Jakarta:Salemba Empat.

Nisa, Haslita. 2018. Pengaruh Rasio Keuangan Terhadap Harga Saham Pada Industri Sektor Pertanian yang Terdaftar di Bursa Efek Indonesia Tahun 2012-2016. Skripsi. Fakultas Ekonomi. Universitas Negeri Yogyakarta.

Sugiyono. 2018. Metode Penelitian Manajemen. Bandung: ALFABETA.

Sujarweni. V Wiratna. 2017. Analisis Laporan Keuangan. Yogyakarta: Pustaka Baru Press.

Sutrisno. Edisi kedua. 2017. Manajemen Keuangan. Yogyakarta: Ekonisia.

Https://www.bi.go.id/id/moneter/bi-7dayRR/data/Contents/Default.aspx

Https://www.bi.go.id/id/statistik/metadata/seki/Doc uments/8Suku_Bunga_Indo_DPM\%20SEKI_2 016\%20(Indonesia)\%20new.Pdf

Https://www.idx.co.id/data-pasar/laporanstatistik/ringkasan-performa-perusahaan-lq45/ 